\title{
CHRONIC DELTA HEPATITIS: FROM DISCOVERY TO NEW TREATMENTS
}

\author{
Adela TURCANU, Suhaib TAHIR WANI \\ Nicolae Testemitanu State University of Medicine and Pharmacy of the Republic of Moldova
}

Corresponding author: Suhaib Tahir Wani, e-mail: wsuhaibtahir@gmail.com

DOI: 10/38045/ohrm.2021.2.03

CZU: 616.36-002-022.7:578.891]-07-085

Keywords: $\quad H D V, \quad$ Introduction. Hepatitis delta virus (HDV) is a small, defective RNA virus that is related HBV, CIRRHOSIS, more to plant viroids than to other human pathogens.

HCC, IVUD (intra-ve- Material and methods. Nearly 50 research articles from various sources were reviewed nous drug users). and a comprehensive analysis was done regarding various parameters concerning HDV.Articles published over a period of 30 years were selected based on their experimental and statistical relevance to HDV. This review gives a brief insight into epidemiology, genetics, clinical evolution and treatment of chronic hepatitis delta.

Results. Chronic hepatitis delta remains a major cause of morbidity in Eastern European countries and the Mediterranean region. At the same time, there is a resurgence of $H B V$ and HDV infection in young people (under the age of 50) in Western Europe, as a consequence of the intra-familial and sexual mode of acquisition among immigrants from Eastern Europe, the Mediterranean region and from countries of the former Soviet Union, Africa high burdened regions of Asia and South America. Prevalence among IVDU was found to be higher especially in western european countries and other regions of low HDV prevalence. Chronic delta viral hepatitis is a dynamic, progressive process. A direct cytopathic pattern of liver tissue damage was also observed, especially in the presence of HDV genotype 3. Chronic hepatitis D is reported to progress to cirrhosis and hepatocellular cancer, and this trend is greater the higher the level of HDV viremia at the time of presentation. Conclusions. Flaws in screening and on-time diagnosis still remain due to the insufficient research and data available. While still not classified as a carcinogen by IARC, our review ends up in support of the notion that HDV infection increases the chances and fastens the pathogenic processes leading to HCC.

Cuvinte cheie: $V H D$, $H B V, C I R R O Z \breve{A}, H C C$, IVUD (consumatori de droguri intra-venoase).

\section{HEPATITA CRONICA DELTA: DE LA DESCOPERIRE LA TRATAMENTE NOI}

Introducere. Virusul hepatic delta (VHD) este un virus ARN mic, defect, care este înrudit mai mult cu viroizii plantelor decât cu alți agenți patogeni umani.

Material si metode. Au fost revizuite ciurca 50 de articole de cercetare din diverse surse și s-a făcut o analiză cuprinzătoare privind diferiți parametrii referitori la VHD. Articolele publicate pe o perioadă de 30 de ani au fost selectate pe baza relevanței lor experimentale și statistice pentru VHD. Această revizuire oferă o perspectivă succintă asupra epidemiologiei, geneticii, evoluției clinice și tratamentului Hepatitei cronice Delta.

Rezultate. Hepatita cronică Delta rămâne o cauză majoră de morbiditate în țările esteuropene și în regiunea mediteraneană. În același timp, există o reapariție a infecției cu VHB și VHD la tinerii (sub 50 de ani) din Europa de Vest, ca o consecință a modului de dobândire intra-familial și sexual în rândul imigranților din Europa de Est, regiunea mediteraneană și din țările din fosta Uniune Sovietică, Africa, regiunile puternic împovărate din Asia și America de Sud. Prevalența în rândul IVDU s-a dovedit a fi mai mare, în special în țările vest-europene și în alte regiuni cu prevalență scăzută a HDV. Hepatita cronică Delta este un proces dinamic, progresiv. De asemenea, s-a observat, un model citopatic direct de țesutul hepatic afectat, în special în prezența genotipului HDV 3. Se raportează că Hepatita cronică D progresează către ciroză și cancer hepatocelular, iar această tendință este mai mare, cu cât este mai mare nivelul de viremie VHD în momentul prezentării.

Concluzii. Rămân în continuare imperfecțiuni în screening și în diagnosticarea la timp din cauza cercetărilor și datelor insuficiente disponibile. Deși încă nu este clasificat ca și cancerigen de IARC, analiza noastră ajunge să susțină ideea, că infecția cu VHD crește șansele și accelerează procesele patogene, care conduc spre HCC. 


\section{INTRODUCTION}

Discovered in 1977 by RIZZETTO and co-workers, Hepatitis delta virus (HDV) is a small, defective RNA virus that is related more to plant viroid's than to other human pathogens (1). It has several unique features. It is not a virus per se but can be described as a defective satellite virus that leads to hepatitis only in the presence of the hepatitis B virus (HBV). HDV has been isolated only from humans (2). On electron microscopy, HDV is an enveloped, spherical, approximately $36 \mathrm{~nm}$ particle that contains a RNA genome of about 1700 nucleotides, the smallest animal viral genome (fig. 1.) (3). Based on structural and biochemical relation of CPEB3 ribozyme to the human hepatitis delta virus (HDV) ribozymes Salehi-Ashtiani postulated that the occurrence of this ribozyme exclusively in mammals suggests that it may have evolved as recently as 200 million years ago and it arose from human transcriptome (4). HDV-like viruses were recently identified in snakes (Boa constrictor) designated snake HDV (sHDV) (5), birds (ducks) (6) and fish, amphibians, invertebrates (7) hence contradicting Salehi-Ashtiani postulation.

Initial studies done by Wang et al., suggested that HDV is a negative stranded virus and contains a single-stranded covalently-closed circular RNA molecule (8). HDV infection can occur simultaneously (co-infection) or as a superinfection with
HBV. At least $5 \%$ of patients with CHB are co-infected with HDV, resulting in a total of 15-20 million HDV-infected individuals worldwide. Data presented by the World Health Organization suggest that, since the 1980s, the overall number of individuals with HDV infection has gradually declined, owing to effective global vaccination programs against HBV. However, HDV-HBV co-infection still represents the most severe form of chronic viral hepatitis because of more rapid disease progression and the development of HCC (9). Clinical outcome of study by Fu et al., showed higher levels of transaminase and bilirubin compared to CHB mono-infection and an increased risk of hepatosplenomegaly along with increased fatigue and jaundice in patients with HBV-HDV co-infection (10). A retrospective, longitudinal study by Butti et al., Long-term changes in the frequency and outcome of hepatitis delta virus (HDV) infection suggested a decline in the circulation of HDV that has resulted in a decrease in acute HDV patients. Chronic HDV appears to be a long-lasting infection with a relatively high propensity to evolve to cirrhosis and slow progression to major liver-related complications, which were more common during the outbreak of the infection (11). Moreover, during the first period of the study, a high percentage of patients with acute HDV were also coinfected with HCV and HIV, viruses that are acquired in the same manner as hepatitis B and D (11).

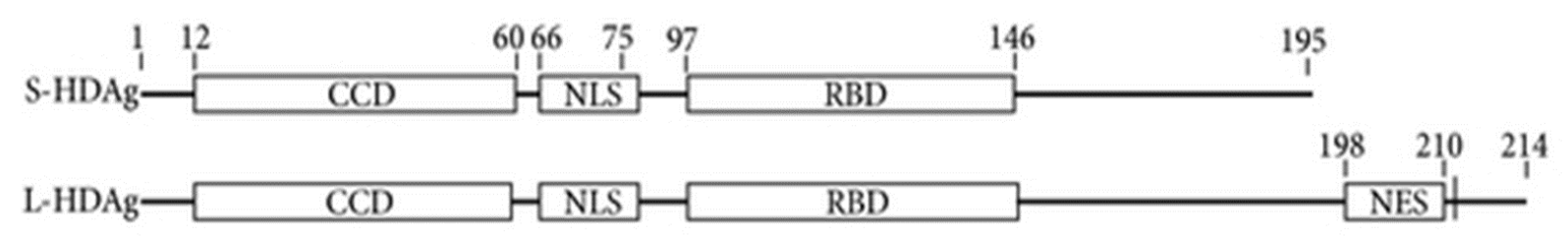

Figure 1. Structure of HDV.

\section{MATERIAL AND METHODS}

We performed a systematic review of earlier studies to analyse the prevalence, pathogenesis, distribution pattern, life cycle and evolution of HDV and new forms of treatment. We searched for articles on the said aspects on PubMed, some journals and other credible online sources like WHO website. Comprehensive analysis of around 50 articles was done and a review put forth in different sub-sections to understand the given parameters mentioned above.

\section{RESULTS}

Our search included studies carried out in diffeent parts of the world and found a varying pattern of distribution with parts of Asia like China, Pakistan, Mongolia, Western and Central Africa, Parts of Eastern Europe and South American countries especially the parts of amazon were found to have a higher burden than countries like USA and western European nations. Although a resurgence is seen în those countries as well due to immigration from Asia, Africa, and other high burdened regi- 
ons like Eastern Europe and South America. In low burdened regions it was found to be more prevalent in IVDU in conjunction with other diseases like HIV that are transmitted on same pattern. Different clads of HDV were found in different parts of the world with HDV type-3 being specific to amazon region. Chronic delta viral hepatitis is a dynamic, progressive process. A direct cytopathic pattern of liver tissue damage was also observed, especially in the presence of HDV genotype 3. Studies also pointed towards the higher propensity of causing HCC. A few new drugs are in the process of production to treat HDV meanwhile eradication of HBV through vaccination or treatment still remains the viable option for preventing HDV infection and its complications. While still not classified as a carcinogen by IARC, our review supports the notion that HDV infection increases the chances and fastens the pathogenic processes leading to HCC.

\section{DISCUSSIONS Epidemiology}

The latest data on the prevalence of chronic delta viral infection indicate approximately 15-20 million people are chronically infected with HDV. Although, recent data provide evidence for a much larger number of people living with HDV. Chen et al suggest that over 60 million people worldwide may be infected with HDV (fig. 1). The authors analysed 182 studies from 61 countries and regions and showed that the overall prevalence of chronic HDV infection was $0.98 \%$. The prevalence of HDV in HBsAg carriers reached $10.6 \%$, which is twice as high as previous estimates. Although several methodological issues have been raised regarding this otherwise well-conducted study, it clearly shows that the number of patients infected with HDV is probably much higher than previous estimates (12). HDV sero-prevalence was also found to be highest in the HBsAg positive IVDU group, followed by the HBsAg HRSB and least in mixed population without any of the two risk factors, further affirmed by a study carried out in Hong Kong concluding that in IVDU who were HBsAg positive, carriage of HDV was almost universal, compared with low rates in non-drug users (13). Prevalence rates vary widely, with higher rates, noted in Africa, South America, Mongolia. Retrospective studies have found that HDV infection is more common in men than women, drug users, men who have sex with men, people living with HIV or HCV and patients with risky sexual behaviour (more sexual partners). Migration and sexual transmission have recently been established as significant risk factors for the acquisition of HDV infection. According to WHO several geographical hot spots of high prevalence of HDV infection: in Mongolia, the Republic of Moldova, and countries in Western and Middle Africa have been identified. Being a co or superinfection with hepatitis B its burden is high in hepatitis B endemic regions with and exception of Vietnam where prevalence of HDV was just $1.3 \%$ in the HBsAg-positive group $(9,14)$.

In the Republic of Moldova, the morbidity index due to acute viral hepatitis $B$ decreased from 25.46 to 100,000 population in 1997 to 0.99 in 2015; by viral hepatitis D (HVD) - from 1.89 to 0.1 in 2015, but the mentioned indices exceed the indices of European countries: Austria - 0.7 cases per 100,000 population, France - 0.2, Germany 0.7 , Hungary -0.6 , Romania -1.6 ; for acute viral hepatitis C: Austria - 1.6 cases per 100,000 population, Hungary - 0.4, Greece - 0.1, Lithuania - 1.3, Estonia - 1.7, Romania - 0.4. At the same time, in the multiannual dynamics there is a slow increase of morbidity due to chronic hepatitis and liver cirrhosis of viral origin: from $35.98 \pm 0.23 \%$ (year 2000 ) to $49.68 \pm 0.19 \%$ (year 2011) for chronic hepatitis and from $22.27 \pm 0.26 \%$ in 2000 to $44.34 \pm 0.72 \%$ in 2011 for cirrhosis of the liver (15).

\section{Replication and Pathogenesis}

Entry of HBV and HBD viruses into the host cell represent the initial phase of infection and follows a stepwise process. Being entirely dependent on the HBV virus for its final assembly HDV shares the same envelope protein as HBV virus that encodes 3 types of envelope proteins named according to their sizes as L (LARGE), M (MEDIUM) and S (SMALL). L, M and S, exist with and without carbohydrate modifications. The L protein undergoes an essential myristylation of a glycine residue penultimate to the N-TERMINUS.S is a common c-terminal domain while additional $\mathrm{N}$ terminal sequences in $\mathrm{M}$ are referred to as preS2. $\mathrm{L}$ compared to $\mathrm{m}$ has additional $\mathrm{N}$-terminal sequences known as preS1 (16). Credible evidence demonstrates the key role played by L-proteins both in attachment and infectivity of the HBV, however, the role of M-proteins and in particular the preS2 domain remains a topic conflict (17). Although preS2's activator function on $\mathrm{PKC} / \mathrm{c}$ - 
RaF-1/MAP2-Kinase signaling cascade exerts a tumor-promotor-like function and eventually development of HCC (18). Yan et al. using near zero distance photo-cross-linking and tandem affinity purification, showed that preS1 interacts with sodium taurocholate cotransporting polypeptide (NTCP) (19).

NTCP belongs to a family of solute carrier proteins SLC10.NTCP is one of the bile salt transporters located in enterohepatic circulation of bile salts and is important for coping with changes in hepatic bile salt load and is expressed mainly in liver (20). In order to attach the hepatocytes, the L-protein rich HBV particles bind to heparin sulphate as demonstrated by Schulze et al, and marks the beginning of multi-step entry process of HBV virus that cannot be achieved via alternate routes (21).

Eight major clades of Hepatitis D virus have been identified (22). Systematic review by Heidar et al. highlighted global distribution of Hepatitis D genotypes. HDV I had a global distribution, HDV II is found mainly in East Asian countries like China, Taiwan, Japan. HDV III circulation was found exclusively in South American countries like PERU, Venezuela and Brazil. African HDV was found mostly in West African countries like Nigeria, Sierra Leone and Liberia. Gabon and Uk showed high prevalence of HDV 5, 6, 7 and 8 while Nigeria and Australia showed moderate prevalence (23).

Several ORFs are included in genetic organization of HDV-genome. Those ORFs include ORF1, ORF2, ORF6, ORF7 and ORF5. All HDV ORFs greater than 300 nucleotides beginning with an ATG are aligned with the circular coordinates of the HDV genome. ORF5 encodes the immunogenic epitope(s) of both delta antigen polypeptides p278 and p248 which can be detected on immunoblots and in immunostaining assays of HDAg-positive liver sections and both p278 and p248 are entirely encoded by ORF5 (24). The mechanism of HDV RNAgenome replication and sub genomic m-RNA transcription is still unclear. However, like some plant viroid's HDV RNA exploits the host DNA-dependent-RNA-polymerase for replication. Delivery of the viral RNA to the nucleus (where RNA replication takes place), is most likely reliant on the combined RNA-binding and nuclear localizing abilities of the HDAg present as part of the infecting ribonucleoprotein complex (25). HDAgs upregulate the expression of a nucleolar phosphoprotein called B23 that has functional importance in nuclear transport, cellular proliferation and ribosome biogenesis. In addition to these functions, it forms complexes with both HDAgs especially the smaller unit and regulates the replication process (26). HDV RNA replication is thought to be similar to viroid replication in plants via double rolling model proposed by Branch and Robertson 1984 which suggests that the circular genomic HDV RNA serves as a template for the antigenomic strand and as the synthesis proceeds, the antigenomic HDV RNA monomers are cleaved from the growing transcript by the action of ribozyme intrensic to both HDV RNA polarities and the resulting RNA species are ligated into circular form that was initially thought to be self-ligation based on Sharmeen et al. self-ligation experiments, however, their results were contradicted in later studies by Read and Lazinski based on functional analogy of one of the mammalian ligase purified from wheat germ extract that can ligate and circularize viroid RNA and viroid's, like HDV , are circular RNAs believed to adopt an unbranched rod like structure and replicated via the rolling circle mechanism $(27,28,29)$. As shown in earlier studies as well, HDAg is of myriad importance. Furthermore, despite being of primary importance for replication of HDV RNA, Harichandran et al, in their study have shown that the level of HDAg required for synthesis of mRNA necessary to form a genome RNP template functional for transcription is capped i.e. it is not required beyond a certain level (30). The role of two different forms of HDAg i.e. S-HDAg and L-HDAg vary. S-HDAg is the one that predominantly transports HDV ribonucleoprotein to the site of replication, starts and maintains replication of HDV genome, while as, LHDAg plays the suppressor role by supressing the function of S-HDAg, suggesting a possible self-limiting infectious mechanism although L-HDAg is not expresed until the later stage of replication. LHDAg is also a potent activator of certain transcription promoters such as the AP-1 binding site (30-33).

\section{Evolution of HDV}

As mentioned earlier Fu et al., showed higher levels of transaminase and bilirubin compared to CHB mono-infection and an increased risk of hepatosplenomegaly along with increased fatigue and jaundice in patients with HBV-HDV co-infection (10). 
Chronic HDV results in most severe form of viral hepatitis and has a high propensity to progress into cirrhosis/fibrosis, with an estimated three fold increase in progression to cirrhosis and a 2fold increase in risk of death when compared to HBV mono-infection. Moreover Development of HCC in HDV infection remains a problem of concern since liver cancer is the second most com mon cause of cancer deaths as shown in a study by Ferlay et al $(11,34)$. HBV-HDV co-infected patients are found to be at a greater risk of HCC development yet in IARC monograph its classified as group 3 i.e., Not classifiable as to its carcinogenicity to humans, due to lack of enough evidence (35).

Cirrhosis is considered as the pathogenic hallmark of liver injury and a premalignant condition virtually for all cases of HCC (36). Thus, evaluation of HDV's role in progression of cirrhosis becomes important. Comparative studies between HBV-HDV co-infection and HBV mono-infection have shown an overall trend favouring the viewpoint of more progressive cirrhosis and HCC incidence in case of HBV-HDV co-infection (tab. 1).

Table 1. Particularities of HDV in different country.

\begin{tabular}{ll}
\hline \multicolumn{1}{c}{ Place of study } & \multicolumn{1}{c}{ Results } \\
\hline BELGIUM & $\begin{array}{l}\text { The patients coinfected with HBV and HDV had higher }(P<0.05) \text { ALT values and more } \\
\text { advanced liver disease (Metavir score } \geq F 2), \text { but had less active HBV replication and } \\
\text { lower HBV DNA titters when compared with the patients infected only with HBV (37). }\end{array}$ \\
\hline GAMBIA & $\begin{array}{l}\text { Consistent with previous reports, HBV-HDV-coinfected Gambians had a highly in- } \\
\text { creased risk of HCC or cirrhosis (without HCC) compared to uninfected or HBV-mo- } \\
\text { noinfection people (38). }\end{array}$ \\
\hline \multirow{3}{*}{ KURE, JAPAN } & $\begin{array}{l}\text { Among 69 cases where anti-HD was detected, eight (12\%) developed liver cirrhosis (LC) } \\
\text { and six (9\%) developed hepatocellular carcinoma (HCC). However, among 1058 cases } \\
\text { without anti-HD, there were 43 patients (4\%) who developed LC and 29 (3\%) who de- } \\
\text { veloped HCC. The prevalence of LC and HCC was significantly higher among the cases } \\
\text { with anti-HD than those without anti-HD (39). }\end{array}$ \\
\hline MAURITANIA & $\begin{array}{l}\text { In Mauritania, HDV co-infection worsens liver disease, both clinically and biologically, } \\
\text { as confirmed by the APRI and FibroMeter tests. These tests may be useful for the man- } \\
\text { agement of delta hepatitis, which is a major health problem in Mauritania (40). }\end{array}$ \\
\hline MOLDOVA & $\begin{array}{l}\text { In HDV infected patients HCC was diagnosed in patients younger than those with other } \\
\text { types of viral hepatitis. Larger tumours were found in HDV-positive patients. Higher } \\
\text { CLIP score and universal presence of cirrhosis was also found (41). }\end{array}$ \\
\hline PAKISTAN & $\begin{array}{l}\text { Children with HDV infection have more aggressive liver disease than HBV monoinfec- } \\
\text { tion irrespective of HBeAg status (42). }\end{array}$ \\
\hline BRAZIL (AMAZON) & $\begin{array}{l}\text { The clinical profile suggested greater severity of liver disease among the patients super- } \\
\text { infected with HDV (43). }\end{array}$ \\
\hline
\end{tabular}

Based on the conclusions of above studies from different countries its highly likely that HDV has a tendency to aggravate or fasten cirrhosis and cause HCC in HBV-HDV co-infected patients. However, a study from TAIWAN stands as an exception being the only one to suggest that Hepatitis D virus superinfection does not accelerate the development of hepatocellular carcinoma (44).

HBV-HDV infection might show a similar clinical course as HBV monoinfection with non-specific symptoms like fatigue, nausea, and hyporexia and are accompanied by the elevation of serum alanine transaminase (ALT) and aspartate transaminase (AST) levels. Even the histological aspects of HDV infection are not different from other forms of viral hepatitis. Increased level of ALT and AST can be associated with high degree of inflammati-on and fibrosis. HDV may possibly play an important and direct role in the establishment of necroinflammatory activity and fibrosis $(45,46)$.

Given the unusual nature of its structure that differentiates it from other virus's treatment of HDV infection is challenging due the failure of HBV-specific nucleoside analogues to suppress HBV helper function and the limitations of experimental systems in the study of the life cycle of HDV. Those limitations have prevented the development of HDV-specific drugs and vaccines. In fact, their has been little or no changes in approach to therapy of chronic HDV infection 
since the 1980s. Being too small to encode the complex proteins required for independent replication it relies entirely on the replicative mechanisms of hepatocytes for its synthesis hence HDV does not provide any target for antiviral attack.

According to Mario Rizzetto "elimination of delta hepatitis, all people in the risk group must be vaccinated, as well as all people with hepatitis B who meet the criteria for treatment, and those who do not meet the standard criteria for antivi-ral treatment must be properly monitored" (47).

Over the years better understanding of relevant molecular virology has led to the identification of new therapeutic candidates (tab. 2). Therapeutic options are: i) inhibition of L-HDAg protein farnesyl permissive virion assembly, ii) blocking HBsAg entry into liver cells by inhibi-ting sodium taurocholate cotransport receptor, to prevent the spread of HDV to uninfected particle hepatocytes, iii) to prevent the synthesis of subviral HBsAg particles leading to reduced virion morphogenesis. However, interferon-alpha (IFN) therapy still remains the principle therapeutic option for HDV infection while pegylated IFN- $\alpha$ is the first-choice treatment for chronic hepatitis $\mathrm{D}$, and a 1-year course should be offered to all IFN- $\alpha$-naive patients, as well as to previous non-responders to standard IFN- $\alpha$ (48).

Table 2. New therapeutic candidates for HDV infection.

\begin{tabular}{ll}
\hline \multicolumn{1}{c}{ Myrcludex B } & $\begin{array}{l}\text { Myristoylated 47-amino acids peptide, preS1-domain derivative of L-HBsAg pro- } \\
\text { tein, that works by inactivating the host NTCP receptor, thus inhibiting HBV/HDV } \\
\text { entry into the host cell (19). }\end{array}$ \\
\hline REP2139 & $\begin{array}{l}\text { Nucleic acid polymers believed to act by inhibition of viral entry and blockade of hepatitis } \\
\text { B virus surface antigen (HBsAg) release and secretion of subviral particles, enabling res- } \\
\text { toration of the host immune response against the virus (49). }\end{array}$ \\
\hline Lonafarnib & $\begin{array}{l}\text { An oral prenylation inhibitor that acts on the enzyme farnesyltransferase and inhibits vi- } \\
\text { rion assembly (50). }\end{array}$ \\
\hline $\begin{array}{l}\text { Pegylated-inter- } \\
\text { feron-lambda } \\
\text { (peg-IFN- } \boldsymbol{\lambda} \text { ) }\end{array}$ & $\begin{array}{l}\text { IFN-lambda is a type III IFN with structural features, receptor characteristics and biologi- } \\
\text { cal activities that are distinct from IFN-alpha, while sharing common interferon-stimu- }\end{array}$ \\
\hline
\end{tabular}

\section{CONCLUSIONS}

1.Despite being the smallest human pathogen, HDV remains to be a cause of concern due to limitations and challenges that arise given the insufficient data and research available. Most patients remain undiagnosed, a situation also reflected in official statistics, which have the total number of people diagnosed in Europe.

2.It is not known whether current testing policies and strategies succeed in testing the right people at the right time, and whether the healthcare system is able to provide comprehensive care is unknown. Consequently, a large (but undetermined) proportion of the chronically infected population enters care only after they have developed clinical symptoms. Others who remain asymptomatic undergo therapy after going through the early stages of their chronic viral infection.

3.While progress is being made in understanding of the life processes of HDV, studies discussed above are highly suggestive of HDV's role in altering the course of HBV infection, aggravating cirrhosis and eventually increasing the risk of HCC.

\section{CONFLICT OF INTERESTS}

The authors declare no conflict of interests.

\section{REFRENCES}

1. Hughes SA, Wedemeyer H, Harrison PM. Hepatitis delta virus. Lancet. 2011;378(9785):73-85. doi:10.1016/S0140-6736(10)61931-9

2. Yurdaydın C, Idilman R, Bozkaya H, Bozdayi AM. Natural history and treatment of chronic delta hepatitis. J Viral Hepat. 2010;17(11):749-56. doi:10.1111/j.1365-2893.2010.01353.x

3. Rizzetto M, Canese MG, Aricò S, Crivelli 0 , Trepo C, Bonino F, Verme G. Immunofluorescence detection of new antigen-antibody system (delta/antidelta) associated to hepatitis B virus in liver and in serum of HBsAg carriers. Gut. 1977;18 (12):997-1003. doi:10.1136/gut.18.12.997

4. Salehi-Ashtiani K, Lupták A, Litovchick A, Szostak JW. A genomewide search for ribozymes reveals an HDV- like sequence in the human CPEB3 gene. 
5. Hetzel U, Szirovicza L, Smura T, Prähauser B, Vapalahti O, Kipar A, Hepojoki J. Identification of a Novel Deltavirus in Boa Constrictors. mBio. 2019;10(2):e00014-19. doi:10.1128/mBio. 00014-19

6. Wille M, Netter HJ, Littlejohn M, Yuen L, Shi M, Eden JS, et al. A Divergent Hepatitis D-Like Agent in Birds. Viruses. 2018;10(12):720. doi:10.3390/ v10120720

7. Chang WS, Pettersson JH, Le Lay C, Shi M, Lo N, Wille M, Eden JS, Holmes EC. Novel hepatitis Dlike agents in vertebrates and invertebrates. Virus Evol. 2019;5(2):vez021. doi:10.1093/ve/vez021

8. Wang KS, Choo QL, Weiner AJ, Ou JH, Najarian RC, Thayer RM, et al. Structure, sequence and expression of the hepatitis delta (delta) viral genome. Nature. 1986;323(6088):508-14. doi:10.1038/ 323508a0

9. WORLD HEALTH ORGANIZATION. Hepatitis D. WHO. 2020. Available: https://www.who.int/ news-room/fact-sheets/detail/hepatitis-d [Accessed 15th January 2021].

10. Fu J, Guo D, Gao D, Huang W, Li Z, Jia B. Clinical analysis of patients suffering from chronic hepatitis B superinfected with other hepadnaviruses. J Med Virol. 2016;88(6):1003-9. doi:10.1002/ jmv.24417

11. Buti M, Homs M, Rodriguez-Frias F, Funalleras G, Jardí R, Sauleda S, et al. Clinical outcome of acute and chronic hepatitis delta over time: a long-term follow-up study. J Viral Hepat. 2011;18(6):43442. doi:10.1111/j.1365-2893.2010.01324.X

12. Chen HY, Shen DT, Ji DZ, Han PC, Zhang WM, Ma $\mathrm{JF}$, et al. Prevalence and burden of hepatitis D virus infection in the global population: a systematic review and meta-analysis. Gut. 2019;68 (3):512-521. doi:10.1136/gutjnl-2018-316601

13. Abbas Z, Jafri W, Raza S. Hepatitis D: Scenario in the Asia-Pacific region. World J Gastroenterol. 2010;16(5):554-62. doi:10.3748/wjg.v16.i5.554

14. Nguyen VT, McLaws ML, Dore GJ. Highly endemic hepatitis B infection in rural Vietnam. J Gastroenterol Hepatol. 2007;22(12):2093-100. doi:10. 1111/j.1440-1746.2007.05010.x

15. Turcanu A. Hepatopatie cronica virala delta - de la hepatita cronica la carcinoma hepatocelular. Monografie. Chisinau, 2018.

16. Taylor JM. Virus entry mediated by hepatitis B virus envelope proteins. World J Gastroenterol. 2013;19(40):6730-4. doi:10.3748/wjg.v19.i40.6730

17. Urban Stephan. New insights into hepatitis $B$ and hepatitis delta virus entry. Future Virology - FU TURE VIROL. 2008.

18. Hildt E, Hofschneider PH. The PreS2 activators of the hepatitis B virus: activators of tumour promoter pathways. Recent Results Cancer Res. 1998;154:315-29. doi:10.1007/978-3-642-
46870-4_23

19. Yan H, Zhong G, Xu G, He W, Jing Z, Gao Z, et al. Sodium taurocholate cotransporting polypeptide is a functional receptor for human hepatitis B and D virus. Elife. 2012;1:e00049. doi:10.7554/eLife. 00049

20. Stieger B. The role of the sodium-taurocholate cotransporting polypeptide (NTCP) and of the bile salt export pump (BSEP) in physiology and pathophysiology of bile formation. Handb Exp Pharmacol. 2011;(201):205-59. doi:10.1007/978-3642-14541-4_5

21. Schulze A, Gripon P, Urban S. Hepatitis B virus infection initiates with a large surface protein-dependent binding to heparan sulfate proteoglycans. Hepatology. 2007;46(6):1759-68. doi:10. 1002/hep.21896

22. Le Gal F, Gault E, Ripault MP, Serpaggi J, Trinchet JC, Gordien E, Dény P. Eighth major clade for hepatitis delta virus. Emerg Infect Dis. 2006; 12(9):1447-50. doi:10.3201/eid1209.060112

23. Sharafi H, Rezaee-Zavareh M S, Miri S M, Alavian S M. Global Distribution of Hepatitis D Virus Genotypes: A Systematic Review. Hepat Mon. 2020; 20(2):e102268. doi:10.5812/hepatmon.102268

24. Weiner AJ, Choo QL, Wang KS, Govindarajan S, Redeker AG, Gerin JL, Houghton M. A single antigenomic open reading frame of the hepatitis delta virus encodes the epitope(s) of both hepatitis delta antigen polypeptides p24 delta and p27 delta. J Virol. 1988;62(2):594-9. doi:10.1128/ JVI.62.2.594-599.1988

25. Macnaughton TB, Lai MM. HDV RNA replication: ancient relic or primer? Curr Top Microbiol Immunol. 2006;307:25-45. doi:10.1007/3-540-298029_2

26. Huang WH, Yung BY, Syu WJ, Lee YH. The nucleolar phosphoprotein B23 interacts with hepatitis delta antigens and modulates the hepatitis delta virus RNA replication. J Biol Chem. 2001;276(27): 25166-75. doi:10.1074/jbc.M010087200

27. Branch AD, Robertson HD. A replication cycle for viroids and other small infectious RNA's. Science. 1984;223(4635):450-5. doi:10.1126/science. 6197756

28. Sharmeen L, Kuo MY, Taylor J. Self-ligating RNA sequences on the antigenome of human hepatitis delta virus. J Virol. 1989;63(3):1428-30. doi:10. 1128/JVI.63.3.1428-1430.1989

Reid CE, Lazinski DW. A host-specific function is required for ligation of a wide variety of ribozyme-processed RNAs. Proc Natl Acad Sci U S A. 2000;97(1):424-9. doi:10.1073/pnas.97.1.424

Harichandran K, Shen Y, Stephenson Tsoris S, Lee SC, Casey JL. Hepatitis Delta Antigen Regulates mRNA and Antigenome RNA Levels during Hepatitis Delta Virus Replication. J Virol. 20193; 93(8):e01989-18. doi:10.1128/JVI.01989-18 
29. Chao M, Hsieh SY, Taylor J. Role of two forms ofhepatitis delta virus antigen: evidence for a mechanism of self-limiting genome replication. J Virol. 1990;64(10):5066-9. doi:10.1128/JVI.64.10. 5066-5069.1990

30. Goto T, Kato N, Ono-Nita SK, Yoshida H, Otsuka M, Shiratori Y, Omata M. Large isoform of hepatitis delta antigen activates serum response factor-associated transcription. J Biol Chem. 20001; 275(48):37311-6. doi:10.1074/jbc.M002947200

31. Li YJ, Macnaughton T, Gao L, Lai MM. RNA-templated replication of hepatitis delta virus: genomic and antigenomic RNAs associate with different nuclear bodies. J Virol. 2006;80(13):647886. doi:10.1128/JVI.02650-05

32. Ferlay J, Soerjomataram I, Dikshit R, Eser S, Mathers C, Rebelo M, et al. Cancer incidence and mortality worldwide: sources, methods and major patterns in GLOBOCAN 2012. Int J Cancer. 2015;136(5):E359-86. doi:10.1002/ijc.29210

33. WORLD HEALTH ORGANIZATION. Hepatitis $D$. WHO. Available: https://www.who.int/ newsroom/fact-sheets/detail/hepatitis-d [Accessed 27 th july 2020].

34. Shackel, N. A., Patel, K., McHutchison, J. Cirrhosis. Genomic and Personalized Medicine. 2013;935 954. doi:10.1016/b978-0-12-382227-7.00078-1

35. Ho E, Deltenre P, Nkuize M, Delwaide J, Colle I, Michielsen P. Belgian Association for the Study of the Liver. Coinfection of hepatitis B and hepatitis delta virus in Belgium: a multicenter BASL study. Prospective epidemiology and comparison with HBV mono-infection. J Med Virol. 2013;85(9): 1513-7. doi:10.1002/jmv.23653

36. Mahale P, Aka P, Chen X, Pfeiffer RM, Liu P, Groover S. et al. Hepatitis D virus infection, cirrhosis and hepatocellular carcinoma in The Gambia. J Viral Hepat. 2019;26(6):738-749. doi:10.1111/ jvh.13065

37. Tamura I, Kurimura O, Koda T, Ichimura H, Katayama S, Kurimura T, Inaba Y. Risk of liver cirrhosis and hepatocellular carcinoma in subjects with hepatitis B and delta virus infection: a study from Kure, Japan. J Gastroenterol Hepatol. 1993;8(5):433-6. doi:10.1111/j.1440-1746. 1993.tb01543.x

38. Lunel-Fabiani F, Mansour W, Amar AO, Aye M, Le Gal F, Malick FZ, et al. Impact of hepatitis B and delta virus co-infection on liver disease in Mauritania: a cross sectional study. J Infect. 2013;67(5): 448-57. doi:10.1016/j.jinf.2013.06.008

39. Turcanu A. Hepatocellular carcinoma in HDV infected patients from Republic of Moldova: from risk factors to survival. Eurasian journal of clinical sciences, 2019;2(2):11. doi:10.28942/ejcs. v2i2.64

Date of receipt of themanuscript: 09/02/2021 Date of acceptance for publication: 11/03/202
40. Abbas Z, Soomro GB, Hassan SM, Luck NH. Clinical presentation of hepatitis D in Pakistani children. Eur J Gastroenterol Hepatol. 2014;26(10):1098103. doi:10.1097/MEG.0000000000000168

41. Oliveira MS, Silva RPM, Valle SDCND, Souza RM, Figueiredo EN, Taminato M, Fram DS. Hepatitis B and Delta: clinical aspects of patients in the Brazilian Western Amazonia. Rev Bras Enferm. 2019;72(5):1265-1270. doi:10.1590/00347167-2018-0100

42. Huo TI, Wu JC, Lai CR, Lu CL, Sheng WY, Lee SD. Comparison of clinico-pathological features in hepatitis B virus-associated hepatocellular carcinoma with or without hepatitis D virus superinfection. J Hepatol. 1996;25(4):439-44. doi:10. 1016/s0168-8278(96)80202-9

43. Liao B, Zhang F, Lin S, He H, Liu Y, Zhang J, et al. Epidemiological, clinical and histological characteristics of HBV/HDV co-infection: a retrospective cross-sectional study in Guangdong, China. PLoS One. 2014;9(12):e115888. doi:10.1371/journal. pone.0115888

44. Braga WS, de Oliveira CM, de Araújo JR, Castilho Mda C, Rocha JM, Gimaque JB, Silva ML, Vasconcelos HL, Ramasawmy R, Paraná R. Chronic HDV/HBV co-infection: predictors of disease stage a case series of HDV-3 patients. J Hepatol. 2014;61(6):1205-11. doi:10.1016/j.jhep.2014. 05.041

45. Țurcanu Adela. Hepatopatia cronică virală Delta: de la hepatită cronică la carcinom hepatocellular. Chisinau, 2018.

46. European Association for the Study of the Liver. Electronic address: easloffice@easloffice.eu; European Association for the Study of the Liver. EASL 2017 Clinical Practice Guidelines on the management of hepatitis B virus infection. J Hepatol. 2017 Aug;67(2):370-398. doi:10.1016/j.jhep. 2017.03.021. Epub 2017 Apr 18. PMID: 28427875.

47. Vaillant A. Nucleic acid polymers: Broad spectrum antiviral activity, antiviral mechanisms and optimization for the treatment of hepatitis B and hepatitis D infection. Antiviral Res. 2016 Sep;133:3240. doi:10.1016/j.antiviral.2016. 07.004. Epub 2016 Jul 9. PMID: 27400989.

48. Glenn JS, Marsters JC Jr, Greenberg HB. Use of a prenylation inhibitor as a novel antiviral agent. J Virol. 1998 Nov;72(11):9303-6. doi:10.1128/ JVI.72.11.9303-9306.1998. PMID: 9765479; PMCID: PMC110351.

49. Mentha N, Clément S, Negro F, Alfaiate D. A review on hepatitis D: From virology to new therapies. J Adv Res. 2019;17:3-15. Published 2019 Mar 29. doi:10.1016/j.jare.2019.03.009 